\title{
The Leadership and Motivation on Inpatient Compliance in Preventing the Risk of Patients Falling
}

\author{
M. Arifki Zainaro ${ }^{1 *}$, Ridwan Ridwan ${ }^{1}$, Rias Tusianah ${ }^{1}$,Usastiawaty C.A.S Isnainy ${ }^{1}$, Tubagus Ali \\ Rachman Puja Kesuma ${ }^{1}$, Albet Maydiantoro ${ }^{1}$
}

${ }^{1}$ Program Doktor FKIP Universitas Lampung, Indonesia

*email: m.arifkiz@yahoo.com

\begin{abstract}
The purpose of this study was to analyze the relationship between leadership and motivation in compliance with inpatient nurses in preventing the risk of falling in patients at X1 Hospital Bandar Lampung in 2020. Pre-survey data on nurses in receiving newly hospitalized patients at a hospital in Bandar Lampung Indonesia in December 2019 found several cases concerning nurses' tasks: did not lower the patients' beds, did not label the patients with the triangles, did not carry out Morse Fall Scale score (MFS) assessments, did not give patients' wristbands the risk of falling, did not install fences of the bed. So far, there has been no incidence of falling patients, however, if there is no effort of preventing, there is a risk of falling patients. This study was a quantitative design and used an analytical cross-sectional approach. The population was of all inpatient nurses at a hospital in Bandar Lampung. The samples in this study were all inpatient nurses totaling 97 nurses. This study used a total sampling technique.The author concludes that 1) the leadership given is not good, 2) motivation is on a moderate scale, 3) the nurse is in the non-obedient category, 4) there is a leadership relationship with inpatient nurse compliance in preventing the risk of falling in patients, and 5) there is a relationship motivation with inpatient nurse compliance in preventing the risk of falling in patients. This article provides new insights regarding the management of fall patients in the context of healthcare practice in Indonesia
\end{abstract}

Keywords

Leadership, Motivation and Compliance

\section{BACKGROUND}

Patient safety is the most important global issue. Now there are many reports about patient demands for medical errors that occur to patients (Kalra, J., Kalra, N., \&Baniak, N. 2013; James, J. T. 2013; Longtin, Y., Sax, H., Leape, L. L., Sheridan, S. E., Donaldson, L., \&Pittet, D. 2010). Hospital patient safety is a system where the hospital provides patient care that seeks more safety. The system includes risk assessment, patient risk identification, and management, incident reporting and analysis, the ability to learn from incidents and follow-up, and implement solutions to minimize risks and prevent injuries caused by mistakes. Errors in action can be a result of carrying out an action or not taking the action that should be taken, such as preventing the risk of falling on a patient (Ministry of Health, 2017; Lawton, R., McEachan, R. R., Giles, S. J., Sirriyeh, R., Watt, I. S., \& Wright, J. 2012; Donaldson, L. J., Panesar, S. S., \& Darzi, A. 2014).

Efforts to anticipate and prevent falling patients need assessment. Assessments can be carried out periodically, including potential risks associated with the drug administration schedule and taking actions to reduce all identified risks. This is the reason why there must be leadership in the team organization because it is one of the duties and roles of the leader in the team organization to anticipate accidents in patients. This fall risk assessment has been carried out since the patient enrolled, using the drop scale (Chassin, M. R., \& Loeb, J. M. 2013; Reason, J. 2016; Chassin, M. R., \& Loeb, J. M. 2013; Sujan, M. 2015).

The Patient Safety team formed by the PantiWaluyo Hospital Surakarta has designated the Morse Fall Scale (MFS) as the instrument used to identify the risk of falling patients. The calculation on MFS is a way to determine the patient's risk of falling and fall prevention management that needs to be carried out in accordance with the existing standard fall prevention operational procedures and applies to all units in the hospital, especially in the inpatient room (Djatmiko, 2016).

Services to patients in the hospital should be a holistic service. Services start from the time the patient arrives, registers, checks until the patient 
goes home. However, some incidents at the hospital sometimes have not reached that far, namely patients falling while getting service at the hospital, both outpatients and as inpatients (Leigh, H. 2013; Ball, J. C., \& Ross, A. 2012; Dranove, D. 2009; Van Keer, R. L., Deschepper, R., Francke, A. L., Huyghens, L., \&Bilsen, J. 2015; Raleigh, V., Thompson, J., Jabbal, J., Graham, C., Sizmur, S., \& Coulter, A. 2015).

Hospital health service facilities are for various patients with various conditions and various causes of the disease. Each patient is a unique person with a variety of needs and characteristics of each. In the case of the disease, there are also various kinds of patient conditions that will affect the way of providing services and care provided because the patient's condition is full of risks. One of the risks that may arise is the patient falling (fall). The implementation of the patient safety program is one indicator of whether or not the implementation of this program is running ( $\mathrm{Ni}$ Panjawi Journal, 2016; Ponikowski, P., Anker, S. D., AlHabib, K. F., Cowie, M. R., Force, T. L., Hu, S, \&Samal, U. C. 2014; Mirzaei, M., Aspin, C., Essue, B., Jeon, Y. H., Dugdale, P., Usherwood, T., \& Leeder, S. 2013).

According to the World Health Organization (WHO), the year defines a fall as an event that results in a person falling accidentally on the ground or floor or a lower level. The hospital has made efforts to reduce or prevent falls, including evaluating the patient's risk of falling and taking immediate action to reduce the risk of falls and reduce the risk of injury from falls. Falling prevention is a complex issue, which crosses boundaries of health, social services, public health, and accident prevention (WHO, 2016; MiakeLye, I. M., Hempel, S., Ganz, D. A., \&Shekelle, P. G. 2013; Abreu, C., Mendes, A., Monteiro, J., \& Santos, F. R. 2012; Igual, R., Medrano, C., \& Plaza, I. 2013).

In England and Wales, approximately 152,000 patients report an acute fall in hospital each year, with more than 26,000 being reported from mental health units and 28,000 from community hospitals. Several cases resulted in death, serious or moderate injury with an estimated cost of \pm 15 million per year (Abraham, S. P. 2012).

The hospital establishes a fall risk reduction program based on appropriate policies and/or procedures. This program monitors the desired or unwanted consequences of actions taken to reduce falls. Hospitals must implement this program, therefore the Joint Commission International (JCI) standard in target 6 states that hospitals need to develop approaches to reduce the risk of injury to patients due to falls, on the other hand providing training to all health workers on how to prevention of the patient's risk of falling is very important. Thus all health workers can have maximum performance in dealing with the risk of falling patients (Johnston, M., \&Magnan, M. A. 2019; Rodziewicz, T. L., \&Hipskind, J. E. 2020; Ryan-Fogarty, Y., O'Regan, B., \& Moles, R. 2016; Kocakulah, M. C., Austill, D., \& Henderson, E. 2019).

Data on the risk of falling patients at Hospital X1 in Bandar Lampung, in 2017 the incidence of falling patients reached 21 patients, in 2018 it reached 24 patients and in 2019 it reached 28 patients. Different from Hospital X2 in Bandar Lampung, in 2017 the incidence of falling patients reached 12 patients, in 2018 it reached 10 patients and in 2019 it reached 8 patients. The data says that the implementation of prevention of the risk of falling patients in X1 Hospital is higher than in X2 Hospital in Bandar Lampung (Profile of the Lampung Provincial Health Office, 2019).

According to the Institute of Medicine, action or negligence is one of the determinants of falls that can harm the patient, but does not cause damage as a result of chance; prevention or mitigation of near injury and no incidents of harm can provide much valuable information that cannot be captured by adverse events reporting system. Therefore, reporting incidents should be encouraged. For this reason, a careful calculation of developing large databases is needed and will also employ more staff for data management, should be considered (Jefriyaga, 2015; Rodziewicz, T. L., \&Hipskind, J. E. 2020; Slawomirski, L., Auraaen, A., \&Klazinga, N. S. 2017).

Referring to patient safety standards, the organization must design a new leadership process or improve the existing process, namely monitoring and evaluating performance through data collection, intensive analysis of incidents, and making changes to improve patient performance and safety. Hospitals need to create an open and fair leadership and culture, lead and support staff in building a strong and clear commitment and focus, integrate risk management 
activities in developing risk management systems and processes and identify and assess services that have potential to become a problem (Kemenkes RI, 2017; Brunsveld-Reinders, A. H., Arbous, M. S., De Vos, R., \& De Jonge, E. 2016; Yusof, M. M. 2015; Papp, J. 2018; Jabri, M. 2017)

The incidence of falling patients is detrimental to the patient. One of the effects is physical injury which includes abrasions, tearing wounds, bruises, even in some serious cases, falls can result in fractures, bleeding and head injuries (Rachmawati, 2019; Aryee, E., James, S. L., Hunt, G. M., \& Ryder, H. F. 2017; Sattar, S., Alibhai, S. M., Spoelstra, S. L., \& Puts, M. T. 2019; Christian, C. W., \& Committee on Child Abuse and Neglect. 2015; Jain, V., Chari, R., Maslovitz, S., Farine, D., Bujold, E., Gagnon, R., ... \& Gouin, K. 2015).

Nurses who have great leadership support tend to have greater levels of adherence as well. Nurses who have moderate levels of leadership support tend to have moderate levels of adherence (Asiri, S. A., Rohrer, W. W., Al-Surimi, K., Da'ar, O. O., \& Ahmed, A. 2016; Houghton, C., Meskell, P., Delaney, H., Smalle, M., Glenton, C., Booth, A., ... \&Biesty, L. M. 2020). Meanwhile, nurses with low leadership support tended to be disobedient. Nurse non-compliance is to identify patients in the application of patient safety (Triyaningsih, 2014).

The Patient Safety Goal (PSG) is a requirement to be applied in all hospitals accredited by the Hospital Accreditation Commission (HAC). One of the factors in implementing the PSG is the motivation of the medical personnel in carrying out patient safety procedures. The use of a patient identification bracelet is the implementation of the first of the 6 Patient Safety Goals. The target of this implementation is the accuracy of patient identification so that patients who are hospitalized in the hospital can identify their needs precisely at the time of service and treatment (Jia, Q., Xu, W. D., Hu, J. H., Liu, J., Liu, H., Zhao, J., \& Zhu, L. Y. 2020; Small, S. 2017).

The implementation of patient safety standards really needs support and a leadership role so that self-motivation in improving patient safety can reach these standards (Kossaify, A., Hleihel, W., \&Lahoud, J. C. 2017; Tan, K. H., Pang, N. L., Siau, C., Foo, Z., \& Fong, K. Y. 2019; Smeds Alenius, L. 2018).

For that, each hospital requires the formation of a patient safety committee that deals with the risk of falling patients (Sujan, M. 2015; Mitchell, I., Schuster, A., Smith, K., Pronovost, P., \& Wu, A. 2016). Harrington (2009) concluded that there are seven steps a leader can take in a hospital to help achieve patient safety. The seven steps include: 1) building awareness of the value of patient safety; 2) lead and support staff, 3) integrate risk management activities; 4) developing a reporting system; 5) engage and communicate with patients; 6) learn and share experiences about patient safety; 7) preventing injury through system implementation. The application of these seven steps can be used as a way to prevent falling patients.

Since the application of Standard Operating Procedures (SOP) at Hospital X1 Bandar Lampung from August to October 2019, it was found that 3 patients had fallen. This was caused by an error in calculating the Instrumental Morse Fall Scale score (MFS). The principles of MFS assessment are part of the performance and behavior of nurses to work in accordance with their duties in the organization. This conformity is usually related to nursing compliance. Obedience is obedience or disobedience to orders and is the starting point for changes in individual attitudes and behavior (Darmadi, 2008).

Based on pre-survey data conducted by researchers on January 15, 2020, researchers have observed 10 nurses receiving 15 new patients who were treated in the inpatient room of Hospital X1 Bandar Lampung in December 2019. Of the 15 patients, it was found that there were 3 patients whose bed was not lowered, 5 patients were not given a triangle label, 2 patients did not undergo an MFS assessment, 2 patients were not given a fall risk bracelet, 3 patients had no bed fence attached. So far, there has been no fall in the patient but if the condition is continued, one day there will definitely be a risk for the patient to fall.

The results of the pre-survey above illustrate that the implementation of safe nursing care to patients which refers to patient safety is not optimal. This could be due to the nurses' lack of knowledge in implementing fall risk management procedures and/or nurses who are not obedient in carrying out SPO, the risk of falling is caused by the procedure being too long, too complicated, and also lacking 
control from superiors. Efforts to prevent patients from falling at risk still need to be a concern for nurses at X1 Hospital in Bandar Lampung.

Based on the description above, the researchers are interested in conducting research with the title: "The Relationship of Leadership and Motivation on Inpatient Compliance in Preventing the Risk of Falling in Patients at X1 Hospital Bandar Lampung in 2020".Based on this background, this study aims to answer the following research questions:

1. How good is the leadership given to the nurses at X1 Bandar Lampung Hospital in 2020?

2. How high is the motivation of the nurses at $\mathrm{X} 1$ Bandar Lampung Hospital in 2020?

3. Are the nurses at X1 Bandar Lampung Hospital in 2020 obeying?

4. Is there a leadership relationship with inpatient nurse compliance in preventing the risk of falling for patients at X1 Hospital in Bandar Lampung in 2020 ?

5. Is there a relationship between motivation and compliance with inpatient nurses in preventing the risk of falling for patients at X1 Hospital in Bandar Lampung in 2020?

\section{METHOD}

This type of research used in this research is quantitative. The research design used an analytical cross-sectional approach, carried out at X1 Hospital Bandar Lampung, June 25 - July 02, 2020. The research subjects were all inpatient nurses at X1 Hospital Bandar Lampung, totaling 97 nurses because the respondents were <100 respondents.

\section{RESULTS}

The nurses who are the source of the research data have demographic data which includes age, gender, education, and length of time carrying out virginity duties. Clearly, the authors present it in table 1 below. The following is a demographic table of participants who became respondents in this study.

Table 1 Demographic Data of Respondents

\begin{tabular}{|c|c|c|c|}
\hline No & Demographic Data & Total & Percentage $(\%)$ \\
\hline \multirow[t]{4}{*}{1} & Age & & \\
\hline & $25-32$ years & 52 & 53,6 \\
\hline & $33-43$ years & 45 & 46,4 \\
\hline & Total & 97 & 100,0 \\
\hline \multirow[t]{4}{*}{2} & Gender & & \\
\hline & Male & 54 & 55.7 \\
\hline & Female & 43 & 44.3 \\
\hline & Total & 97 & 100,0 \\
\hline \multirow[t]{5}{*}{3} & Education & & \\
\hline & D3 & 43 & 44.3 \\
\hline & Ns & 30 & 30.9 \\
\hline & S1 & 24 & 24.7 \\
\hline & Total & 97 & 100,0 \\
\hline \multirow[t]{2}{*}{4} & Service Period & & \\
\hline & 1 year & 4 & 4.1 \\
\hline
\end{tabular}




\begin{tabular}{ccc}
\hline 2 years & 24 & 24.7 \\
\hline 3 years & 11 & 11.3 \\
\hline 4 years & 35 & 36.1 \\
\hline 5 years & 7 & 7.2 \\
\hline 8 years & 16 & 16.5 \\
\hline Total & 97 & 100,0 \\
\hline
\end{tabular}

Source: 2020 research data processing

Table 2 The calculated variable data

\begin{tabular}{cccc}
\hline No & Variable & Total & Percentage (\%) \\
\hline 1 & Leadership & & \\
\cline { 2 - 4 } & Good & 31 & 32.0 \\
\cline { 2 - 4 } & Not good & 66 & 68.0 \\
\cline { 2 - 4 } 2 & Total & 97 & 100,0 \\
\cline { 2 - 4 } & Motivation & & 33.0 \\
\cline { 2 - 4 } & $\begin{array}{c}\text { Strong } \\
\text { Motivation }\end{array}$ & 32 & 35.1 \\
\cline { 2 - 4 } & $\begin{array}{c}\text { Medium } \\
\text { Motivation }\end{array}$ & 34 & 32.0 \\
\cline { 2 - 4 } & $\begin{array}{c}\text { Weak } \\
\text { Motivation }\end{array}$ & 31 & 100,0 \\
\cline { 2 - 4 } & Total & 97 & 43.3 \\
\hline 3 & Obedience & 56.7 \\
\cline { 2 - 4 } & Obey & 42 & 100,0 \\
\cline { 2 - 4 } & Disobedience & 55 & 97 \\
\cline { 2 - 4 } & Total & & \\
\hline
\end{tabular}

Source: 2020 research data processing

Table 2 shows that at Hospital X1 Bandar Lampung in 2020, respondents stated that from the aspect of leadership: good $=31(32 \%)$ and bad $=66(68.0 \%)$; motivation: $32(33 \%)$ strong, 34 $(35.1 \%)$ moderate, and 31 (32\%) weak; adherence: adherent $42(43.3 \%)$ and non-adherent $55(56.7 \%)$.

To find out the relationship between leadership and motivation to nurses' obedience in caring for overnight patients in preventing the risk of falling for patients at Hospital X1 in Bandar Lampung in 2020, using the Chi-Square Test: 
Table 3 Chi-Square Test

\begin{tabular}{|c|c|c|c|c|c|c|c|c|}
\hline \multirow[t]{3}{*}{ Leadership } & \multicolumn{4}{|c|}{ Compliance } & \multirow{2}{*}{\multicolumn{2}{|c|}{ Total }} & \multirow{3}{*}{$\begin{array}{l}\text { P- } \\
\text { Value }\end{array}$} & \multirow[t]{3}{*}{ OR $95 \% \mathrm{Cl}$} \\
\hline & \multicolumn{2}{|c|}{ Obey } & \multicolumn{2}{|c|}{ Disobey } & & & & \\
\hline & $\mathrm{N}$ & $\%$ & $\mathrm{~N}$ & $\%$ & $\mathrm{~N}$ & $\%$ & & \\
\hline Good & 21 & 67,7 & 10 & 32,3 & 31 & 100,0 & 0,002 & $4,500(1,804$ \\
\hline Not good & 21 & 31,8 & 45 & 68,2 & 66 & 100,0 & & $-11,224)$ \\
\hline total & 42 & 43,3 & 55 & 56,7 & 97 & 100,0 & & \\
\hline
\end{tabular}

Source: 2020 research data processing

The Relationship between Leadership and Nurse Compliance in Caring for Overnight Stay Patients in Preventing the Risk of Falling Patients

Based on the results of statistical tests in table 3, it was found that the $\mathrm{p}$-value was 0.002 or $\mathrm{p}$-value $<\alpha$ (0.05), which means that there was a relationship between leadership and the compliance of nurses who cared for overnight patients in preventing the risk of falling in patients at X1 Hospital in Bandar Lampung. 2020 with an OR value of 4,500, which means that respondents who get bad leadership will have a 4,500 times greater chance of disobeying.

The Relationship between Motivation and Nurse Compliance in Caring for Overnight Stay Patients in Preventing the Risk of Falling Patients

Table 4 Statistical Test for Univariate Discussion

\begin{tabular}{lccccccc}
\hline Motivasi & \multicolumn{3}{c}{ Kepatuhan } & \multicolumn{3}{c}{ Total } & \multirow{2}{*}{ P-Value } \\
\cline { 2 - 6 } & \multicolumn{3}{c}{ Patuh } & \multicolumn{3}{c}{ TidakPatuh } & \\
\cline { 2 - 6 } & $\mathrm{N}$ & $\%$ & $\mathrm{~N}$ & $\%$ & $\mathrm{~N}$ & $\%$ & \\
\hline MotivasiKuat & 19 & 59,4 & 13 & 40,6 & 32 & 100 & 0,000 \\
\hline MotivasiSedang & 19 & 55,9 & 15 & 44,1 & 34 & 100 & \\
\hline MotivasiLemah & 4 & 12,9 & 27 & 87,1 & 31 & 100 & \\
\hline Jumlah & 42 & 43,3 & 55 & 56,7 & 97 & 100
\end{tabular}

Source: 2020 research data processing

Based on the results of statistical tests table 4 , a pvalue of 0,000 was obtained or $p$-value $<\alpha(0.05)$, which means that there is a relationship between

\section{DISCUSSION}

\section{Leadership}

Nursalam (2016), states that leadership is an activity to influence the behavior of others, or the art of influencing human behavior, both individually and in groups. Leadership is one of the most important factors in an organization because most of the success and failure of an motivation and compliance of inpatient nurses in preventing the risk of falling in patients at X1 Hospital Bandung in 2020.

organization is determined by the leadership in the organization.

Leadership as a group of processes carried out by someone in managing and inspiring a number of jobs to achieve organizational goals through the application of management techniques. In essence, leadership has a rather broad understanding compared to management. 
Management is a special type of thinking of leadership in an effort to achieve organizational goals. Meanwhile, leaders may try to achieve organizational or group goals, and they may be the same or aligned or not in line with organizational goals (Pohan, 2017).

Based on the results of the research and theory above, it is in line with the research of Gilang (2015) regarding the relationship between leadership support and nurse compliance in the implementation of Fall Patient Prevention Measures at Government Y Regional General Hospital, states that most of the respondents get poor leadership support.

In general, the average leadership is still weak or not good, such as the leadership cannot coordinate with all subordinates with an emphasis on a sense of responsibility regarding the risk of falling patients, the leadership does not delegate authority to their subordinates if needed and the leadership does not provide direction if there is a nurse who is wrong in doing measures to prevent the risk of falling patients, while based on the filling in the questionnaire sheet, it was found that there were some good leaders, such as leadership communication in giving assignments quickly and clearly, the leadership paid attention to the lack of needs for facilities and infrastructure in preventing the risk of falling patients and the leadership provided guidance with quickly, precisely and easily to his subordinates regarding the risk of falling on the patient.

\section{Motivation}

The term motivation comes from the Latin word "movere" which means to push or move. Motivation questions how to direct power and potential to work towards the specified goals (Pohan, 2017). Basically, a person works because he wants to make ends meet. The urge to desire in a person is different so that human behavior tends to vary at work. Motivation refers to a process of influencing individual choices for various forms of desired activity. In addition, the term includes a number of concepts of drive, need, incentive, reward, reinforcement, goal setting, expectancy, and so on.

Work motivation is motivation that occurs in situations and work environments in an organization or institution. Success and failure in education are often linked to teacher work motivation. Basically, humans always want things that are fine, so that the driving force or driving force that motivates their work spirit depends on the expectations that will be obtained in the future, if those hopes come true, someone will tend to increase their work motivation (Nursalam, 2016).

The same thing was also conveyed by Jefriyaga (2015) regarding the relationship between nurses 'motivation and nurses' compliance in carrying out patient safety management at X2 Hospital in Lampung, saying that most respondents had weak motivation.

Based on the results of the research above, according to the researcher, the average respondent has weak motivation, this is because based on the questionnaire filled out by the respondent it is known that why the respondent has weak motivation because the salary/wages are not according to the predetermined schedule, the work load that is held not in accordance with the wages earned, and the work relationship with other nurses 'co-workers is not good and lacks effective communication, while there are some that make the respondents' motivation strong, including the responsibilities given have been adjusted to the respective abilities of the nurses, the leadership has involved subordinates in solving problems and if there are nurses who have work performance, they will be given rewards/awards.

\section{Obedience}

Professional nurse compliance is the extent to which a nurse's behavior is in accordance with the provisions given by the nurse's leadership or the hospital. Compliance is a human behavior that obeys rules, orders, procedures and discipline. Nurse compliance is the behavior of nurses as a professional towards recommendations, procedures or regulations that must be carried out or obeyed (Pohan, 2017).

Based on the results of the research and theory above, it is in line with Zulkifli's research on the relationship between work tenure and nurse compliance in the implementation of Fall Patient Prevention Measures at the Samarinda 
Government Regional General Hospital, which states that most of the respondents were not compliant, totaling 72 respondents $(57.3 \%)$.

Based on the results of the research and discussion above, according to the researchers some respondents did not comply because based on the questionnaire it was known that nurses did not routinely document the risk of falling patients, nurses did not routinely analyze the risk of falling patients in accordance with existing regulations and policies and in assessing patient risks. fall, nurses rarely follow orders from the leadership, and vice versa, there are some nurses who are obedient, this is because, the nurse routinely assesses the risk of falling patients during surgery, the nurse always tells other shift nurses about the progress of the patient's risk of falling and the nurse conducts an assessment the patient is at risk of falling when the patient first enters and when the patient's physical changes occur.

\section{The Leadership Relationship between Nurse Compliance in caring for hospitalized patients in the prevention of the risk of falling patients}

Based on the results of statistical tests (table 3), pvalue is 0.002 or $p$-value $<\alpha(0.05)$, which means that there is a leadership relationship with nurses' compliance in caring for overnight patients in preventing the risk of falling patients at Hospital X1 Bandar Lampung in 2020, with an OR value of 4,500. It means that respondents who get bad leadership are 4,500 times more likely to disobey.

The Patient Safety Goal (PSG) is a requirement to be implemented in all hospitals accredited by the Hospital Accreditation Commission (HAC). One of the factors in implementing PSG is the motivation of medical personnel in carrying out patient safety procedures, such as the use of patient identification bracelets, which is the first implementation of the 6 Patient Safety Targets, namely the accuracy of patient identification which aims to be able to correctly identify patients hospitalized in the hospital at the time of providing services or medication. One of the patient safety standards is the role of leadership and motivation in improving patient safety in the form of leadership support and self-will in implementing these standards (Djatmiko, 2016).
Every hospital needs the establishment of a patient safety committee that handles the risk of falling patients. There are seven steps a leader can take in a hospital to help achieve patient safety. The seven steps include: building awareness of the value of patient safety, leading and supporting staff, integrating risk management activities, developing reporting systems, engaging and communicating with patients, learning and sharing experiences about patient safety, and preventing injuries through system implementation. The application of these seven steps can be used as a way to prevent falling patients (Djatmiko, 2016).

Since the implementation of Standard Operating Procedures (SPO) at Hospital X1 in Bandar Lampung by identifying patients at risk of falling in August-October 2019, it was found that 3 patients had fallen; this was due to an error in calculating the score from the Instrument Morse Fall Scale. One of the efforts to prevent falling patients is through the MFS assessment. The principles of MFS assessment are part of the performance and behavior of nurses in working according to their duties in the organization, usually related to compliance. Obedience is compliance or disobedience to orders, and is the starting point for changes in individual attitudes and behavior (Djatmiko, 2016).

The results of the research and discussion above are in line with the research of $\mathrm{Ni}$ PanjawiLacshitaJati, et al (2016) regarding Nurse Compliance in Implementing Standard Operating Procedures to Prevent Falling Patients Based on Demographic and Motivational Factors, stating that the analysis shows that the higher the motivation of nurses, the higher the compliance of nurses in implementing SPO for Patient Prevention. Fall down. In addition, there is a significant relationship between compliance with motivational factors with a p-value of 0.002 or $p$ value $<0.05$. It is recommended for the hospital to hold socialization, increase the motivation of nurses, and provide appreciation, training and commitment in implementing SPO for fall patient prevention.

Based on the results of the above research, according to the researchers, there is a relationship 
between leadership and compliance in preventing the risk of falling on patients, this is because most respondents think that the existing leadership is not good, this is due to a lack of direction, evaluation and support from the leadership, resulting in nurses not obedient to the implementation of risk management for falling patients in the hospital, but in the results of the study the researchers also found that some respondents received good leadership support, but respondents were less obedient in implementing the risk management of falling patients, this was due to other factors that influenced such as, lack of effective communication between nurses, a work environment that is not conducive, a lack of rewards / rewards given to nurses or even age factors that are no longer productive, this is evidenced by the presence of an OR value of 4,500 , which means the respondent who gets The bad leadership is 4,500 times more likely to be disobedient, so the effect or consequence of bad leadership will have a big impact on the level of compliance of respondents.

Based on the results of data recapitulation from respondents' answers on the questionnaire sheet, it is known that several problems were identified, including the following: The leader involved us in making decisions to handle fallen patients, the leader delegated tasks to other nurses, if the nurse did not know about prevention the risk of falling patients and the leadership does not pay attention to the lack of facilities and infrastructure needs in preventing the risk of falling patients.

\section{Relationship between Motivation and Nurse Compliance in caring for Overnight Stay Patients in the Prevention of Fall Risk}

Based on the results of statistical tests, a p-value of 0,000 was obtained or $p$-value $<\alpha(0.05)$, which means that there is a relationship between motivation and compliance with inpatients in preventing the risk of falling in patients at $\mathrm{X} 1$ Hospital Bandar Lampung in 2020 (see table 4) .

The term motivation comes from the Latin word "movere" which means to push or move. Motivation questions how to direct power and potential to work towards the specified goals (Pohan, 2017). Basically, a person works because he wants to make ends meet. The urge to desire in a person is different so that human behavior tends to vary at work. Motivation refers to a process of influencing individual choices for various forms of desired activity. In addition, the term includes a number of concepts of drive, need, incentive, reward, reinforcement, goal setting, expectancy, and so on.

According to Sinambela (2018) motivation contains three main components, namely a) to move, means to generate strength in the individual to lead someone to act in a certain way, b) directing or channeling behavior. In doing so it provides a goal orientation. Individual behavior is directed towards something, c) to maintain or sustain behavior, the environment must strengthen (reinforce) the intensity, urges and strengths of the individual.

According to Jefriyaga's (2015) research on the relationship between nurses 'motivation and compliance with nurses in carrying out patient safety management at Bhayangkara Hospital, Lampung, it is stated that there is a significant relationship between nurses' motivation and compliance with nurses in carrying out patient safety management with a p-value $<0.05$, namely 0.001 .

Based on the results of the research and discussion above, according to the researcher there is a relationship between motivation and compliance of nurses in implementing the risk of falling patients, this is because most respondents have weak motivation, this is due to a lack of attitude and considers that handling risk management of falling patients is not very important as well as the lack of rewards or awards given to nurses so that it has an impact on the lack of compliance of nurses in carrying out risk management for falling patients, but in the results of the study the researchers also found that there were respondents who had strong motivation, but nurses were still not obedient to the implementation of prevention of falling patient risk This is because based on the results of filling out the questionnaire, it is known that nurses do not carry out their duties and responsibilities in accordance with the direction of the leadership, nurses do not analyze the risk of falling patients in accordance with existing 
regulations and policies, and Don't routinely document the risk of falling patients.

In the variable of the relationship between motivation and compliance, there is no OR value, this is because in the data analysis the researcher did, the available bivariate table was not $2 \times 2$, so automatically the OR value on the variable of motivation and compliance did not appear.

Based on the results of the data recapitulation from the respondents' answers on the questionnaire sheet, it is known that several problems were identified: The workload carried out was not in accordance with the salary obtained, nurses who were dissatisfied with the work environment determined by the hospital, nurses and co-workers did not provide enthusiasm for work and if there are nurses who have work performance, they will not be given a reward.

\section{CONCLUSIONS}

Based on the results of the research, the conclusions in this study are that (1) the leadership given was not good, (2) the nurses motivation is on a moderate scale, (3) most of the respondents were not compliant, (4) there was relationship between inpatient nurse compliance in preventing the risk of falling in patients, and (5) there was a motivational relationship between inpatient nurse compliance in preventing the risk of falling in patents.

\section{IMPLICATION}

The authors suggest based on the results of this study to:

\section{For Policy}

The results of this study provide additional knowledge about the relationship of leadership and motivation to inpatient nurse compliance in preventing the risk of falling in patients and are expected to be used as a basis for further research.

\section{For Further Researchers}

This study has not reached the factors that increase and weaken the motivation and compliance of nurses, so further research can examine these factors.

\section{For HospitalX1 Bandar Lampung}

The results of this study can be used as a reference for holding seminars or health training on inpatient leadership, motivation and compliance in preventing the risk of falling in patients, so as to produce excellent service.

\section{For The Nurses}

The results of this study is new knowledge about the importance of compliance in implementing the risk of falling patients prevention by following the directions given by the leadership, conducting regular assessments and evaluations of the risk of falling patients and communicating and collaborating well with colleagues.

\section{REFERENCES}

[1] Abreu, C., Mendes, A., Monteiro, J., \& Santos, F. R. (2012). Falls in hospital settings: a longitudinal study. Revistalatino-americana de enfermagem, 20(3), 597-603.

[2] Aprina. (2015). RisetKeperawatan. Lampung: Pendidikan Diklat Lampung.

[3] Aryee, E., James, S. L., Hunt, G. M., \& Ryder, H. F. (2017). Identifying protective and risk factors for injurious falls in patients hospitalized for acute care: a retrospective case-control study. BMC geriatrics, 17(1), 260.

[4] Asiri, S. A., Rohrer, W. W., Al-Surimi, K., Da'ar, O. O., \& Ahmed, A. (2016). The association of leadership styles and empowerment with nurses' organizational commitment in an acute health care setting: a cross-sectional study. $B M C$ nursing, 15(1), 38.

[5] Ball, J. C., \& Ross, A. (2012). The effectiveness of methadone maintenance treatment: patients, programs, services, and outcome. Springer Science \& Business Media.

[6] Brunsveld-Reinders, A. H., Arbous, M. S., De Vos, R., \& De Jonge, E. (2016). Incident and error reporting systems in intensive care: a systematic review of the literature. International Journal for Quality in Health Care, 28(1), 2-13. 
[7] Chassin, M. R., \& Loeb, J. M. (2013). High- reliability health care: getting there from here. The Milbank Quarterly, 91(3), 459-490.

[8] Christian, C. W., \& Committee on Child Abuse and Neglect. (2015). The evaluation of suspected child physical abuse. Pediatrics, 135(5), e1337-e1354.

[9] Darmadi. (2008).InfeksiNosokomial: Problematika dan Pengendaliannya. Jakarta: Salemba medika.

[10] Dranove, D. (2009). The economic evolution of American health care: from Marcus Welby to managed care. Princeton University Press.

[11] Djatmiko, RiswanDwi. (2016). Keselamatan Dan Kesehatan Kerja. Jakarta: PenerbitBukuDeepublish.

[12] DinasProvinsi Lampung. (2017). Profil Kesehatan Provinsi Lampung. Dinkes: Lampung.

[13] Dharma, Kusuma. (2011). MetodelogiPenelitian. Jakarta: Trans Info Media.

[14] Donaldson, L. J., Panesar, S. S., \& Darzi, A. (2014). Patient-safety-related hospital deaths in England: thematic analysis of incidents reported to a national database, 2010-2012. PLoS Med, 11(6), e1001667.

[15] Harrington. (2009). Buku Saku Kesehatan Kerja. Edisi 3: Penerbit EGC. Cetakan I. Jakarta.

[16] Houghton, C., Meskell, P., Delaney, H., Smalle, M., Glenton, C., Booth, A., ... \&Biesty, L. M. (2020). Barriers and facilitators to healthcare workers' adherence with infection prevention and control (IPC) guidelines for respiratory infectious diseases: a rapid qualitative evidence synthesis. Cochrane Database of Systematic Reviews, (4).

[17] James, J. T. (2013). A new, evidencebased estimate of patient harms associated with hospital care. Journal of patient safety, 9(3), 122-128.

[18] Jeyaratnam J., Koh D. 2010. Buku Ajar. PraktekKedokteranKerja. Jakarta: EGC.

[19] Jain, V., Chari, R., Maslovitz, S., Farine, D., Bujold, E., Gagnon, R., ... \& Gouin, K. (2015). Guidelines for the management of a pregnant trauma patient. Journal of Obstetrics and Gynaecology Canada, 37(6), 553-571.

[20] Jabri, M. (2017). Managing organizational change: Process, social construction and dialogue. Palgrave.

[21] Jefriyaga. M. (2015) tentanghubunganmotivasiperawatterhadap kepatuhanperawatdalammenajalankanma najemen patient safety Di RS Bhayangkara Lampung.

[22] Jia, Q., Xu, W. D., Hu, J. H., Liu, J., Liu, H., Zhao, J., \& Zhu, L. Y. (2020). AS18007| Facial camouflage pattern design based on spot combination and camouflage effect evaluation. Basic Clin PharmacolToxicol, 126(3), 3-189.

[23] Johnston, M., \&Magnan, M. A. (2019). Using a fall prevention checklist to reduce hospital falls: results of a quality improvement project. AJN The American Journal of Nursing, 119(3), 43-49.

[24] Lawton, R., McEachan, R. R., Giles, S. J., Sirriyeh, R., Watt, I. S., \& Wright, J. (2012). Development of an evidence-based framework of factors contributing to patient safety incidents in hospital settings: a systematic review. BMJ quality \& safety, 21(5), 369-380.

[25] Leigh, H. (2013). The patient: Biological, psychological, and social dimensions of medical practice. Springer Science \& Business Media.

[26] Longtin, Y., Sax, H., Leape, L. L., Sheridan, S. E., Donaldson, L., \&Pittet, D. (2010, January). Patient participation: current knowledge and applicability to patient safety. In Mayo Clinic Proceedings (Vol. 85, No. 1, pp. 53-62). Elsevier.

[27] Kalra, J., Kalra, N., \&Baniak, N. (2013). Medical error, disclosure and patient safety: A global view of quality care. Clinical biochemistry, 46(13-14), 1161-1169.

[28] Kemenkes RI. (2017). Profil Kementerian Kesehatan Republik Indonesia Tahun 2017. 
[29] Kuntoro, A. (2010).

Buku Ajar

ManajemenKeperawatan. Yogyakarta: NuhaMedika

[30] Kocakulah, M. C., Austill, D., \& Henderson, E. (2019). Medicare cost reduction in the US: A case study of hospital readmissions and value-based purchasing. International Journal of Healthcare Management, 1-16.

[31] Kossaify, A., Hleihel, W., \&Lahoud, J. C. (2017). Team-based efforts to improve quality of care, the fundamental role of ethics, and the responsibility of health managers: monitoring and management strategies to enhance teamwork. Public health, 153, 91-98.

[32] Miake-Lye, I. M., Hempel, S., Ganz, D. A., \&Shekelle, P. G. (2013). Inpatient fall prevention programs as a patient safety strategy: a systematic review. Annals of internal medicine, 158(5_Part_2), 390396.

[33] Mitchell, I., Schuster, A., Smith, K., Pronovost, P., \& Wu, A. (2016). Patient safety incident reporting: a qualitative study of thoughts and perceptions of experts 15 years after 'To Err is Human'. BMJ quality \& safety, 25(2), 9299.

[34] Mirzaei, M., Aspin, C., Essue, B., Jeon, Y. H., Dugdale, P., Usherwood, T., \& Leeder, S. (2013). A patient-centred approach to health service delivery: improving health outcomes for people with chronic illness. BMC health services research, 13(1), 251.

[35] Mubarak, Wahit Iqbal. (2009). Promosi Kesehatan UntukKebidanan. Jakarta :SalembaMedika

[36] Notoatmodjo, Soekidjo. (2012). MetodelogiPenelitian Kesehatan. Jakarta: RinekaCipta.

[37] Notoatmodjo, Soekidjo. (2010).Promosi Kesehatan dan IlmuPerilaku Kesehatan. Jakarta: RinekaCipta.

[38] Ni PanjawiLacshitaJati. (2016). dkktentangKepatuhanPerawatMelaksanak anStandarProsedurOperasionalPencegah anPasienJatuhBerdasarkanFaktorDemogr afi Dan Motivasi.
[39] Nursalam.

(2016).

ManajemenKeperawatan.

Jakarta:

SalembaMedika.

[40] Papp, J. (2018). Quality Management in the Imaging Sciences E-Book. Elsevier Health

[41] Sciences.

[42] ProfilDinas Kesehatan Provinsi Lampung. (2019). Profil Kesehatan Provinsi Lampung: Lampung.

[43] Pohan, Imbalo, MPH. (2017). JaminanMutuLayanan Kesehatan. Jakarta: EGC.

[44] Ponikowski, P., Anker, S. D., AlHabib, K. F., Cowie, M. R., Force, T. L., Hu, S.,\&Samal, U. C. (2014). Heart failure: preventing disease and death worldwide. ESC heart failure, 1(1), 4-25.

[45] RumahSakit Bintang Amin. (2019). Profil $R S$ Bintang Amin: Lampung.

[46] Riskesdas. (2018). ProfilRiset Kesehatan Dasar Tahun 2018. Departemen Kesehatan: Indonesia.

[47] Rachmawati, Nunung. (2019). Manajemen Patient Safety Konsep\&Aplikasi Patient Safety Dalam Kesehatan. Yogyakarta: PT.PustakaBaru.

[48] Raleigh, V., Thompson, J., Jabbal, J., Graham, C., Sizmur, S., \& Coulter, A. (2015). Patients' experience of using hospital services. London, UK: King's Fund.

[49] Reason, J. (2016). Managing the risks of organizational accidents. Routledge .

[50] Rodziewicz, T. L., \&Hipskind, J. E. (2020). Medical error prevention. In StatPearls [Internet]. StatPearls Publishing.

[51] Ryan-Fogarty, Y., O'Regan, B., \& Moles, R. (2016). Greening healthcare: systematic implementation of environmental programmes in a university teaching hospital. Journal of Cleaner Production, 126, 248-259.

[52] Sattar, S., Alibhai, S. M., Spoelstra, S. L., \& Puts, M. T. (2019). The assessment, management, and reporting of falls, and the impact of falls on cancer treatment in community-dwelling older patients receiving cancer treatment: results from a 
mixed-methods study. Journal of geriatric oncology, 10(1), 98-104.

[53] Small, S. (2017). Treading the line: Seeking balance in information sharing and privacy in ActionADE (Doctoral dissertation, Communication, Art \& Technology: School of Communication).

[54] Smeds Alenius, L. (2018). Conditions for care: factors in the nurse work environment related to safe and high quality care in acute care hospitals.

[55] Setiadi. (2007). Konsep dan PenulisanRisetKeperawatan. Yogyakarta :Graha. Ilmu.

[56] Sinambela, PoltakLijan. (2018). ManajemenSumberDayaManusia. Jakarta: BumiAksara.

[57] Slawomirski, L., Auraaen, A., \&Klazinga, N. S. (2017). The economics of patient safety.

[58] Sugiyono. (2016). Metodologi Pendidikan Penelitian. Bandung: Alfabeta.

[59] Sujan, M. (2015). An organisation without a memory: a qualitative study of hospital staff perceptions on reporting and organisational learning for patient safety. Reliability engineering \& system safety, 144, 45-52.
[60] Sulistyaningsih.

(2016). MetodologiPenelitianKebidananKuantitati f-Kualitatif Yogyakarta: Grahallmu.

[61] Tan, K. H., Pang, N. L., Siau, C., Foo, Z., \& Fong, K. Y. (2019). Building an organizational culture of patient safety. Journal of Patient Safety and Risk Management, 24(6), 253-261.

[62] Yusof, M. M. (2015). A case study evaluation of a critical care information system adoption using the socio-technical and fit approach. International journal of medical informatics, 84(7), 486-499.

[63] Van Keer, R. L., Deschepper, R., Francke, A. L., Huyghens, L., \&Bilsen, J. (2015). Conflicts between healthcare professionals and families of a multi-ethnic patient population during critical care: an ethnographic study. Critical Care, 19(1), $1-13$.

[64] WHO, (2016).Keselamatan Kesehatan Kerja Se-Dunia. WHO: Philadelphia.

[65] Zulkifli.( 2018). tentanghubunganantara masa

kerjadengankepatuhanperawatdalamPelak sanaan Tindakan PencegahanPasienJatuh di RumahSakitUmum Daerah PemerintahSamarinda. 